\title{
The neurosteroid allopregnanolone modulates specific functions in central and peripheral glial cells
}

\author{
Alessandro Faroni ${ }^{1,2}$ and Valerio Magnaghi ${ }^{2}$ * \\ ${ }^{1}$ Blond Mclndoe Laboratories, Regenerative Biomedicine, School of Medicine, The University of Manchester, Manchester, UK \\ ${ }^{2}$ Department of Endocrinology, Physiopathology, Applied Biology, University of Milan, Milan, Italy
}

\author{
Edited by: \\ Hubert Vaudry, University of Rouen, \\ France \\ Reviewed by: \\ Ishwar Parhar, Monash University, \\ Malaysia \\ Michael Schumacher, INSERM \\ France \\ *Correspondence: \\ Valerio Magnaghi, Department of \\ Endocrinology, Physiopathology, \\ Applied Biology, University of Milan, \\ Via G. Balzaretti 9, 20133 Milan, Italy. \\ e-mail: valerio.magnaghi@unimi.it
}

Since the first observations on the existence of "neurosteroids" in the 1980s, our understanding of the importance of these endogenous steroids in the control of the central and peripheral nervous system (PNS) has increased progressively. Although most of the observations were made in neuronal cells, equally important are the effects that neurosteroids exert on glial cells. Among the different classes of neurosteroids acting on glial cells, the progesterone $5 \alpha-3 \alpha$ metabolite, allopregnanolone, displays a particular mechanism of action involving primarily the modulation of classic GABA receptors. In this review, we focus our attention on allopregnanolone because its effects on the physiology of glial cells of the central and PNS are intriguing and could potentially lead to the development of new strategies for neuroprotection and/or regeneration of injured nervous tissues.

Keywords: neuron-glial interaction, GABA, non-genomic action, myelin, Schwann cell

\section{INTRODUCTION}

The first observations on the existence of "nervous steroids" appeared in the early 1980s, introducing the novel concept that some hormonal steroids may be synthesized de novo in the nervous system. Baulieu (1997) coined the term "neurosteroids" in order to define such molecules. Over the years, the importance of such endogenous steroids in the control of both the central nervous system (CNS) and peripheral nervous system (PNS) has become increasingly apparent. However, most of the observations were made through investigations into their role in neuronal cells. Equally important are the putative effects that neurosteroids may directly exert on glial cells by regulating their physiological functions, or even indirectly through the complex interactions with neuronal cells.

It is now generally believed that central (i.e., astrocytes, oligodendrocytes) and peripheral glial cells (i.e., Schwann cells, SC) are fundamental for the regulation of neuronal activity. They

Abbreviations: $3 \alpha$-HSD, $3 \alpha$-hydroxysteroid-dehydrogenase; $3 \beta \mathrm{HSD}, \quad 3 \beta$ hydroxysteroid-dehydrogenase; $5 \mathrm{HT}_{3}, 5$-hydroxytryptamine type $3 ; 17 \alpha \mathrm{HSD}$, $17 \alpha$-hydroxysteroid-dehydrogenase; ALLO, allopregnanolone; AR, androgen receptor; bFGF, basic fibroblast growth factor; CMT1A, Charcot Marie Tooth type 1A; CNPase, 2'-3'-cyclic nucleotide-3-phospodiesterase; CREB, cAMP response element-binding protein; DHP, dehydroprogesterone; EAAC1, excitatory amino acid transporter 1; ER, estrogen receptor; GABA, $\gamma$-aminobutyric acid; GABA-A, GABA type A receptor; GABA-B, GABA type B receptor; GAD67, glutamic acid decarboxylase of $67 \mathrm{kDa}$; GFAP, glial fibrillary acid protein; IGF-I, insulin-like growth factor-I; LHRH, luteinizing-hormone-releasing hormone; MAG, myelin associated glycoprotein; MBP, myelin basic protein; mER, membrane estrogen receptor; $\mathrm{mPR}$, membrane progesterone receptor; NMDA, $N$-Methyl-D-aspartate; P450SCC, P450 cholesterol side-chain cleavage enzyme; P, progesterone; P0, myelin protein zero; PK-A, protein kinase A; PK-C, protein kinase C; PMP22, peripheral myelin protein of $22 \mathrm{kDa}$; PNS, peripheral nervous system; PR, progesterone receptor; $\mathrm{PSA}-\mathrm{NCAM}^{+}$, polysialylated-neural cell adhesion molecule positive cells; SC, Schwann cells; $5 \alpha-R, 5 \alpha$-reductase; T, testosterone; TGF $\alpha$, transforming growth factor $\alpha$; TGF $\beta 1$, transforming growth factor $\beta 1$; TGF $\beta 2$, transforming growth factor $\beta 2 ; \mathrm{TNF} \alpha$, tumor necrosis factor $\alpha$. support neuron metabolism and survival, they can uptake and produce neurotransmitters and they are also able to synthesize neurosteroids (Celotti et al., 1992; Melcangi et al., 2001b). Glial cells, indeed, possess all the enzymatic pathways and the synthetic machinery required to produce steroids (that is the P450 cholesterol side-chain cleavage enzyme, P450SCC; $17 \alpha$-hydroxysteroiddehydrogenase, $17 \alpha$-HSD; $3 \beta$-hydroxysteroid-dehydrogenase, $3 \beta$ HSD and other enzymes), or to convert them into neuroactive metabolites (Mellon et al., 2001). In particular, the enzymatic complex formed by the $5 \alpha$-reductase $(5 \alpha-\mathrm{R})$ and the $3 \alpha-$ hydroxysteroid-dehydrogenase ( $3 \alpha-H S D)$ enzymes has been characterized in several areas of the human brain (Steckelbroeck et al., 2001) and in the PNS (Melcangi et al., 1990b, 1992, 1999b; Celotti et al., 1992). The combined action of these two enzymes catalyzes the conversion of some native steroids, such as progesterone $(\mathrm{P})$, into their more active $5 \alpha-3 \alpha$-reduced metabolites, that is into "neurosteroids." This enzymatic complex is extremely versatile since every steroid possessing the 84 -3keto configuration could potentially undergo the $5 \alpha$-reduction and subsequently be subjected to $3 \alpha$-hydroxylation (Celotti et al., 1992; Melcangi et al., 1999b, 2000c). By analyzing the ability of purified primary cell cultures of neurons, astrocytes (type 1 and type 2 astrocytes) or oligodendrocytes to metabolize testosterone (T; Melcangi et al., 1990a, 1993, 1994), it has been demonstrated that neurons possess significantly higher amounts of $5 \alpha$-R activity compared to astrocytes and oligodendrocytes (Melcangi et al., 1993, 1994). Interestingly, the simultaneous presence of neurons and type 1 astrocyte cultures stimulates the $5 \alpha$-R activity (Melcangi et al., 2001c), indicating a possible interaction of these cells in the metabolism of neurosteroids. It is also reasonable to speculate that the metabolism of neurosteroids may be relevant for differentiation of glia. Gago et al. (2001) showed that the formation of the $5 \alpha$ reduced metabolite of $\mathrm{P}$, dehydroprogesterone (DHP), is fivefold higher in fully differentiated oligodendrocytes compared to oligodendrocyte progenitor cells. This suggests that the acquisition 
of the neurosteroids biosynthetic capacity is a marker of glial differentiation. In addition, the reaction catalyzed by $3 \alpha-H S D$ involves the replacement of a carbonyl with a hydroxyl group, leading to the formation of metabolites that are potent modulators of non-classical steroid receptors (see below). Some biochemical studies demonstrated that $3 \alpha-\mathrm{HSD}$ is distributed in various regions of the rodent brain (Khanna et al., 1995; Mellon et al., 2001; Agis-Balboa et al., 2007), where it is mainly localized in type 1 astrocytes (Melcangi et al., 1993, 1994) and in oligodendrocytes (Melcangi et al., 1994). The $5 \alpha-\mathrm{R}-3 \alpha-\mathrm{HSD}$ activity is also present in the SC of the PNS (Melcangi et al., 1990b, 1998, 1999b; Yokoi et al., 1998). Therefore, the ability to synthesize or metabolize particular arrays of steroids seems to be region-specific in the different CNS areas and confined to glial cells (Mellon et al., 2001). In line with this hypothesis, the $5 \alpha-\mathrm{R}$ activity in the myelin forming cells of the CNS and PNS (that is oligodendrocytes and SC, respectively) appeared different, being about four times higher in SC compared to oligodendrocytes (Melcangi et al., 1998). Thus, the presence of the $5 \alpha$-R-3 $\alpha$-HSD enzymatic complex in oligodendrocytes and SC suggests that the locally formed neurosteroids might play a crucial role in the process of myelination (Melcangi et al., 1988, 2001c; Martini et al., 2003).

The neurosteroid 5 $\alpha$-pregnan-3 $\alpha$-ol-20-one, also named tetrahydroprogesterone or allopregnanolone (ALLO) is the most important hormonal steroid that was originally shown to act as a neurosteroid. It is synthesized through the action of the $5 \alpha \mathrm{R}$ $3 \alpha$-HSD, which converts $\mathrm{P}$ into DHP and subsequently, via a bidirectional reaction, into ALLO (see Figure 1, in SC). Interestingly, ALLO is able to modulate several neuronal cell functions. For instance, it is proven to be a neurogenic molecule, inducing a dose dependent significant increase in proliferation of rat neural progenitor cells and of human neural stem cells (Wang et al., 2005), or affecting cerebellar neurogenesis (Keller et al., 2004). Besides these studies revealing ALLO's actions on the neuronal compartment, several observations have suggested important roles for ALLO on glial cells. In this review we attempt to summarize the intriguing modulations and the therapeutic potential of the neurosteroid ALLO on the glial cells of the CNS and PNS.

\section{MECHANISM OF ACTION OF NEUROSTEROIDS}

Neurosteroids exert complex effects in the nervous system through "classic" and "non-classic" actions. The "classic" genomic action consists of the modulation of their target cells by regulating gene transcription after binding to nuclear receptors (Slater et al., 1994). By contrast, the rapid "non-classic" action involves the modulation of neurotransmitter receptors, that is $\gamma$-aminobutyric acid (GABA), N-Methyl-D-aspartate (NMDA), 5-hydroxytryptamine type $3\left(5 \mathrm{HT}_{3}\right)$ and $\sigma$-receptors (Lambert et al., 1996; Rupprecht et al., 2001; Monnet and Maurice, 2006; Sedlacek et al., 2008) and the activation of novel putative membrane receptors for steroids (Hammes and Levin, 2007; Dressing et al., 2011; Levin, 2011). Some of these receptors have been found in glial cells (see Tables 1-3).

Allopregnanolone is a potent modulator of the GABA type A (GABA-A) receptor (Majewska et al., 1986; Majewska, 1992; Lambert et al., 1995). In fact, the most important and wellcharacterized "non-classic," non-genomic action of neurosteroids is represented by the ALLO's activation of GABA-A receptor functions (Majewska et al., 1986; Rupprecht and Holsboer, 1999; Lambert et al., 2003). Interestingly, ALLO's mechanism of action on GABA-A receptor is concentration dependent. Indeed, in the low nanomolar aqueous concentration ALLO acts allosterically, enhancing the action of the natural ligand GABA, while at higher concentration (micromolar range) ALLO directly gates the GABA-A receptor channel complex (Callachan et al., 1987; Puia et al., 1990). However, it has been shown that neurosteroids may directly gate GABA-A receptors also at lower concentration, around $100 \mathrm{nM}$, but the kinetic of this receptor activation is relatively slow (Shu et al., 2004).

The GABA-A receptor is a member of the ligand-gated ion channel family, permeable to chloride ions and composed of five subunits drawn from a repertoire of 19 isoforms (that is $\alpha 1-6, \beta 1-3, \gamma 1-3, \delta, \varepsilon, \pi, \theta, \rho 1-3$; Whiting et al., 1995, 1997; Lambert et al., 2003). The GABA-A receptor is blocked by bicuculline and picrotoxin, but channel opening is enhanced by benzodiazepines, barbiturates, anesthetics and also neurosteroids (Park-Chung et al., 1999; Belelli and Lambert, 2005). Interestingly, the GABA-A receptor modulation exerted by neurosteroids is enantioselective and is partially dependent upon the receptor subunit composition. For this reason several studies were aimed at elucidating the putative neurosteroids external binding sites (Lambert et al., 2003). Although no special requirement concerning the nature of the $\alpha$ and $\beta$ subunits seems to be essential to confer sensitivity to neurosteroids (Belelli et al., 2002), a receptor composed of one $\alpha(\alpha 2-5)$ assembled with $\beta 3$ and $\gamma 2 S$ subunits gives consistent potentiation of ALLO-mediated GABA-activated currents (Hosie et al., 2009). Moreover, $\gamma 2$ subunits confer more sensitivity than $\gamma 1$ or $\gamma 3$ (Belelli et al., 2002), while $\delta$ subunit potentiates the action of the $5 \alpha-3 \alpha$-reduced neurosteroids (Mihalek et al., 1999; Belelli et al., 2002). The extrasynaptic GABA-A receptor incorporating the $\delta$ subunit, indeed, is an important and highly sensitive target of neurosteroids (Lambert et al., 2009), implicating the $\delta$-containing receptors as the preferred target for the action of neurosteroids. Nevertheless, the $\delta$ subunit seems to primarily influence the transduction of neurosteroid signals rather than engage directly in binding (Hosie et al., 2009).

Neurosteroids might also indirectly target the receptor function by regulating the transcription of some GABA-A receptor subunits, thus altering the GABA-A inhibitory activity for a prolonged time (Maguire and Mody, 2009). Neurosteroids might also interact with protein kinase or phosphatases, which in turn act on GABA-A subunits altering the entire receptor function (Belelli and Lambert, 2005). Likewise, phosphorylation of GABA-A receptors by protein kinase $\mathrm{C}$ (PK-C) influences the sensitivity to neurosteroids (Brussaard and Koksma, 2003; Vergnano et al., 2007).

Beside the external binding sites of GABA-A receptor, some recent evidence supports a novel hypothesis suggesting that neurosteroids require a membranous route of access to transmembrane-domain binding sites within GABA-A receptor (Shu et al., 2004; Akk et al., 2005; Hosie et al., 2006; Chisari et al., 2009). Once neurosteroids reach the site of action they may diffuse through the plasma membrane to directly bind the GABA-A receptor, rather than interacting with external binding sites of the receptor. This is a low-affinity receptor interaction that might 
depend on the lipid composition of the cell membrane. Neurosteroids may be also retained in the intracellular compartment and then re-supply the plasma membrane with ligands able to modulate the GABA-A receptor at later times, so that the rate of this transport can alter the kinetics of neurosteroids actions (Akk et al., 2005).

The proposed mechanisms of ALLO's action, however, may be in principle complementary to the classic genomic effects. Indeed, an indirect action of ALLO involving the classic progesterone receptor (PR) should not be totally excluded. In such a scenario, ALLO's action closely depends on its retro-conversion to DHP, operated by enzyme $3 \alpha$-HSD (Martini et al., 2003), which may then stimulate the PR generating a classic genomic effect. In comparison to ALLO's rapid interaction with GABA-A receptors, the PR-mediated mechanism shows slower kinetics and lasts for a longer time.

Finally, concerning the ALLO interaction with the GABAergic system, its putative ability to interact with the metabotropic GABA-B receptor should not be totally excluded, although the evidence that such an interaction effectively occurs is not clearly provided. GABA-B receptor is a distinct, baclofen-sensitive, metabotropic receptor that is a member of the seven transmembrane G-protein-coupled receptor superfamily. GABA-B receptors may influence the activity of adenylate cyclase and/or modulate calcium and potassium channels activity (Bowery and Enna, 2000). In this regard, we have recently demonstrated in vitro a cross-correlation between the GABA-A and $\mathrm{B}$ receptors in SC (Magnaghi, 2007), and some of these effects are discussed below.

\section{ALLO's EFFECT ON ASTROCYTE}

Neurosteroids are known to control the proliferation, cell shape, and gene expression of CNS astroglia (Garcia-Segura et al., 1996, 1999; Jordan, 1999; Nichols, 1999). The cytoskeletal protein, glial fibrillary acidic protein (GFAP) is usually responsible for modulating astrocyte shape and motility (Laping et al., 1994). Many of the effects of neurosteroids on the expression and synthesis of GFAP are due to their active metabolites. For instance, the gene expression of GFAP in culture of astrocytes is inhibited by ALLO and stimulated by DHP, suggesting that different intracellular signaling pathways are likely to be involved in astrocytes proliferation (Melcangi et al., 1996). Nevertheless, it has been proposed that the ALLO's effects on astrocytes are mediated by the activation of GABA-A receptors, whose subunits are widely distributed in astrocytes (Bovolin et al., 1992; Hosli et al., 1997; Israel et al., 2003). The effects of neuroactive steroids have also been evaluated on ammonia-induced astrocyte swelling in culture, a phenomena that occurs early after some acute CNS pathologies such as ischemia and traumatic brain injury. Bender and Norenberg (1998) showed that nanomolar concentration of ALLO diminishes the astrocyte swelling, likely via a GABA-A mechanism. These observations might be very useful for the development of new therapeutic approaches to treat the acute hyperammonemic syndromes and other associated pathological conditions (Bender and Norenberg, 1998).

Allopregnanolone seems to be also involved in the feedback mechanisms regulating the gonadal axis, and in particular the neuroendocrine function of the luteinizing-hormone-releasing hormone (LHRH). Herbison and collaborators provide the first

Table 1 | Distribution of major classic and non-classic receptors for neurosteroids in astrocytes.

Classic intracellular receptors

\begin{tabular}{ll}
\hline PR & ER \\
\hline $\begin{array}{ll}\text { Rat glial } \\
\text { culture }\end{array}$ & Pig brain areas \\
(Jung-Testas & Wangub and \\
et al., 1992) & \\
& Rat brain \\
& (Azcoitia et al., \\
& 1999; Cardona- \\
& Gomez et al., \\
& 2000; Milner \\
& et al., 2001) \\
& \\
& Rat glial \\
& culture \\
(Jung-Testas \\
et al., 1992; \\
Santagati \\
et al., 1994)
\end{tabular}

AR

Primate
Non-classic membrane receptors

GABA-A

Mouse corpus callosum

prefrontal cortex (Berger et al., 1992)

(Finley and

Kritzer, 1999)

Rat glial culture

(Jung-Testas

et al., 1992)

Rat hypothalamus (Israel

et al., 2003), hippocampus

(Macvicar et al., 1989; Fraser

et al., 1995; Kang et al., 1998)

spinal cord (Chvatal et al.,

1995; Pastor et al., 1995),

optic nerve astrocytes (Butt

and Jennings, 1994)

Rat glial culture (Kettenmann

et al., 1987; Backus et al.,

1988; Bormann, 1988;

Rosewater and Sontheimer,

1994; Hosli et al., 1997;

Matsutani and Yamamoto,

1997)

Human brain and human glial

culture (Lee et al., 2011a,b)

$\begin{array}{lll}\text { NMDA } & \text { mER } & \text { MPR } \\ \text { Rat celebral cortex (Conti et al., } & \text { Rat glial } & \text { Rat spinal } \\ \text { 1996), spinal cord slice (Ziak } & \text { culture (Kuo } & \text { cord (Labom- } \\ \text { et al., 1998), and injured rat } & \text { et al., 2011) } & \text { barda et al., } \\ \text { hippocampus (Krebs et al., 2003) } & & \text { 2011) }\end{array}$

Human celebral cortex (Conti

et al., 1999)

Mouse cortex (Lalo et al., 2006)

and neocortex (Schipke et al.,

2001)

Human glial culture (Lee et al.,

2011a,b) 
Table 2 | Distribution of major classic and non-classic receptors for neurosteroids in oligodendrocytes.

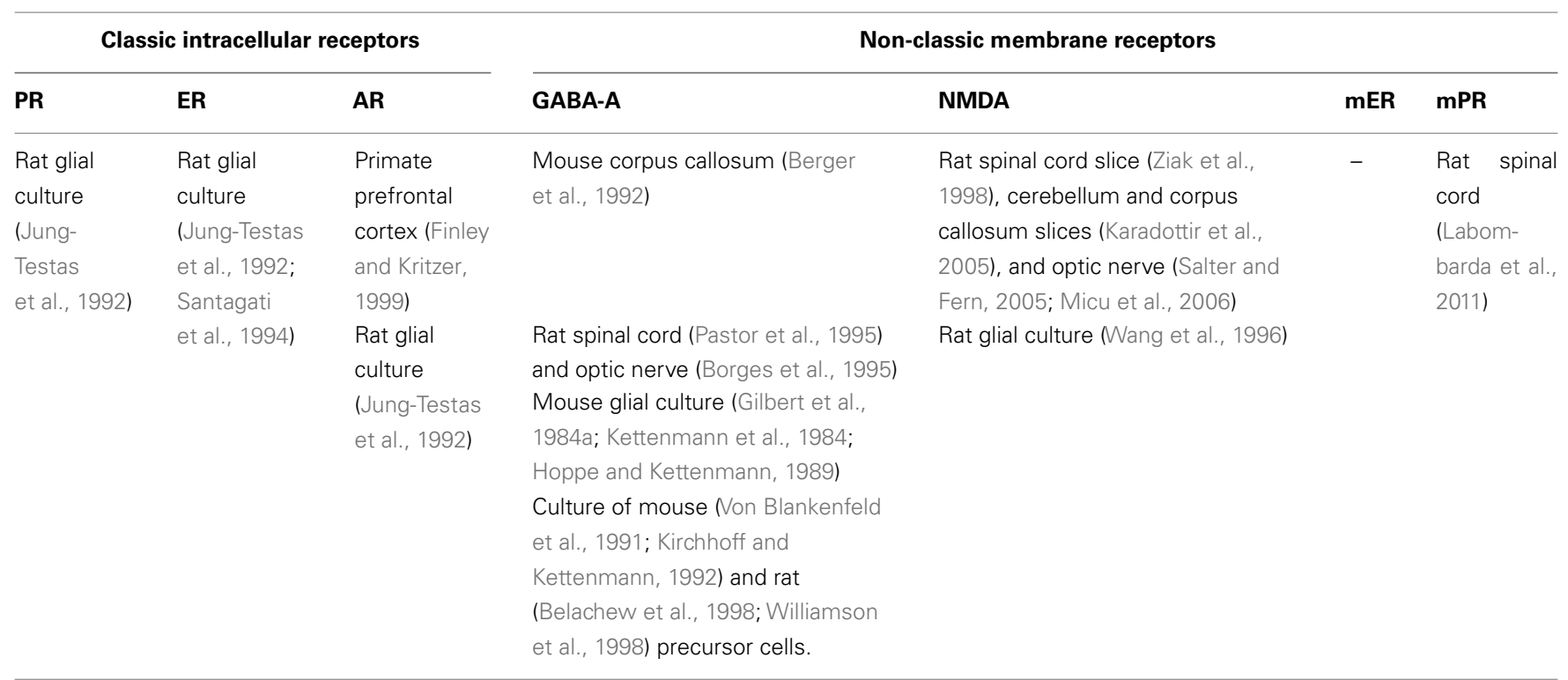

Table 3 | Distribution of major classic and non-classic receptors for neurosteroids in Schwann cells.

\begin{tabular}{|c|c|c|c|c|c|c|}
\hline \multicolumn{3}{|c|}{ Classic intracellular receptors } & \multicolumn{4}{|c|}{ Non-classic membrane receptors } \\
\hline PR & ER & AR & GABA-A & NMDA & mER & mPR \\
\hline $\begin{array}{l}\text { Rat sciatic nerve (Magnaghi et al., } \\
\text { 2001) }\end{array}$ & & & $\begin{array}{l}\text { Rat sciatic nerve } \\
\text { (Melcangi et al., 1999a; } \\
\text { Magnaghi et al., 2006) }\end{array}$ & $\begin{array}{l}\text { Giant squid SC } \\
\text { (Evans et al., } \\
\text { 1991, 1992) }\end{array}$ & & \\
\hline
\end{tabular}

evidence for a direct action of ALLO on postnatal LHRH neurons, suggesting a new mechanism by which fluctuating $\mathrm{P}$ levels may influence the secretory activity of these neurons in the female hypothalamus (Sim et al., 2001). At the cellular level, the increased ALLO concentration, typical of late pregnancy, has important physiological actions in repressing the electrical activity of specific magnocellular oxytocin neurons in the hypothalamus. Moreover, the fall in ALLO concentration prior to parturition equally impacts GABA-A receptor signaling in oxytocin neurons, as well as in the hippocampus and frontal cortex neurons, suggesting that ALLO's concentration changes during pregnancy are likely to exert a powerful regulatory influence upon neurotransmission in a variety of brain networks (Herbison, 2001).

However, paracrine mechanisms involving astrocyte cells may also be at the base of positive or negative feedback signals regulating the reproductive axis. Indeed, growth factors such as transforming growth factor $\alpha$ (TGF $\alpha$ ), transforming growth factor $\beta 1$ (TGF $\beta 1$ ) and $\beta 2$ (TGF $\beta 2$ ), as well as basic fibroblast growth factor (bFGF) and insulin-like growth factor-I (IGF-I) are released by astrocytes and participate in the control of LHRH release (Melcangi et al., 1997; Ojeda and Ma, 1999). ALLO stimulates TGF $\beta 1$ gene expression in hypothalamic astrocytes, nevertheless also $\mathrm{P}$ and DHP proved able to exert an identical effect, suggesting that
ALLO's action may imply an indirect mechanism mediated via PR (Melcangi et al., 2001a).

\section{ALLO's EFFECT ON OLIGODENDROCYTE}

In mature oligodendrocytes (the cells responsible for forming the central myelin) the progestagens neurosteroids regulate the gene expression of some important proteins, such as the myelin basic protein (MBP) and the $2^{\prime}-3^{\prime}$-cyclic nucleotide-3-phospodiesterase (CNPase; Verdi and Campagnoni, 1990; Jung-Testas et al., 1996b). The age-associated decline in MBP expression levels in 22- to 24month-old male rats, for instance, was reversed by ALLO and DHP, still indicating a PR-mediated genomic mechanism (Ibanez et al., 2003). The progestagens involvement on MBP expression regulation in oligodentrocytes was demonstrated also in organotypic slice cultures of 7-day-old rat and mouse cerebellum (Ghoumari et al., 2003). This effect likely involves classic PR, since it was mimicked with the selective PR agonist R5020 and blocked with the PR antagonist mifepristone (Ghoumari et al., 2003). However, ALLO significantly stimulates MBP expression in 7-day-old rat and mouse cerebellum cultures, and this effect seemed to be mediated via GABA-A receptor activation. In accordance, the GABA-A antagonist bicuculline counteracts the ALLO stimulatory effect, confirming a GABA-A-mediated mechanism (Ghoumari et al., 
2003). It is important to underline that some GABA-A receptor subunits are expressed in oligodendrocytes (Gilbert et al., 1984b) and in oligodendrocyte progenitor cells (Kettenmann et al., 1984; Kirchhoff and Kettenmann, 1992). Gago et al. (2004) observed that the neuroactive steroids and GABA signaling are responsible for the autocrine/paracrine loops controlling neuronal progenitors proliferation and differentiation. The neuronal progenitor polysialylated-neural cell adhesion molecule positive cells (PSA$\mathrm{NCAM}^{+}$), indeed, possess several GABA-A receptor subunits (Nguyen et al., 2003; Gago et al., 2004), like the $\alpha 1-5, \beta 2, \beta 3$, and $\gamma 2$ isoforms (Gago et al., 2004). Interestingly, GABA increased in a dose dependent manner the proliferation of these cells and the effect was bicuculline sensitive, suggesting a GABA-A-mediated mechanism. The effect on the PSA-NCAM ${ }^{+}$proliferation was also mimicked by nanomolar concentration of ALLO. Moreover, $\mathrm{P}$ via its conversion in ALLO, proved able to stimulate the early $\mathrm{PSA}^{-N C A M}{ }^{+}$progenitor proliferation (Gago et al., 2004).

Collectively, these findings suggest a pivotal role of ALLO and GABA in the development and maturation of oligodendrocytes (Ben-Ari, 2002; Gago et al., 2004).

\section{ALLO's EFFECT ON MICROGLIA}

Steroids exert anti-inflammatory actions in the peripheral tissues as well as in the brain, where they act mainly on microglial cells. In this regard, some efforts were addressed to study the neuroprotective role of estrogens and progesterone on microglial cells (Stone et al., 1997; Vegeto et al., 1999, 2001; Drew and Chavis, 2000; Bruce-Keller et al., 2001). In parallel, several line of evidence showed that ALLO plays a neuroprotective role following different brain injury conditions, such as ischemic damage (Kelley et al., 2011), PTX-induced seizures (Singh et al., 2010) and oxygenglucose deprivation (Ardeshiri et al., 2006). The concentrations of ALLO are also remarkably high in the fetal brain and further rise in response to acute hypoxia, representing an endogenous protective mechanism in the developing brain (Hirst et al., 2006). These effects might be generally ascribed to ALLO's regulation of antiinflammatory cytokines and endogenous antioxidants, although only few evidences rely on the direct effect of ALLO on microglial cells. For instance, the endogenous concentration of ALLO in the brain is increased concomitantly to the lipopolysaccharidesinduced tumor necrosis factor $\alpha(\mathrm{TNF} \alpha)$ production, which in turn inhibits TNF $\alpha$ levels (Ghezzi et al., 2000). ALLO also protects against apoptotic cell death in an in vivo model of rat prefrontal cortex injury, even if this effects were not totally referred to a microglial cell disregulation (Djebaili et al., 2005).

\section{ALLO's EFFECT ON SC}

Over the last few decades a large body of evidence has accumulated from investigations into the potential effects that neurosteroids exert on SC, which are the cells ensheathing axons and forming the myelin in the PNS (Jessen and Mirsky, 1997). The first studies started when Baulieu and colleagues focused their attention on neurosteroid biosynthesis, analyzing primarily the peripheral nerves, such as the sciatic nerve, and the SC (JungTestas et al., 1993). The progestagens, $\mathrm{P}$ and its $5 \alpha$-derivatives (DHP and ALLO) have been studied in vivo, demonstrating that they are able to modulate several biochemical and morphological parameters of the PNS (Melcangi et al., 2000c; Magnaghi et al., 2001). For instance, progestagens stimulated the expression of specific peripheral myelin proteins, such as the myelin protein zero (P0) and the peripheral myelin protein 22 (PMP22), in the sciatic nerve of young and old male rats (Melcangi et al., 1998, 1999a, 2000c; Magnaghi et al., 2001). Moreover, they reduced myelin abnormalities and fibers loss in aged sciatic nerve (Azcoitia et al., 2003), promoting re-myelination after cryolesion (Koenig et al., 1995), transection (Melcangi et al., 2000a), or crush injury (Roglio et al., 2008). Mifepristone (RU38486), a classic PR antagonist, was recently studied because of its ability in decreasing the PMP22 overexpression in a rat model of peripheral inherited neuropathy (i.e., the Charcot Marie Tooth type 1A, CMT1A; Sereda et al., 2003). These results lead to the conclusion that PR likely participates in the control of specific peripheral myelin proteins, such as P0 and PMP22 (Magnaghi et al., 2001). Nevertheless, in vitro studies showed that ALLO, besides the ability of increasing P0 mRNA levels, is the main neurosteroid able to stimulate the levels of PMP22 mRNA and protein (Melcangi et al., 1999a, 2000b; Magnaghi et al., 2001).

Allopregnanolone is a potent modulator of GABA-A receptor, which subunits are widely distributed in SC (Melcangi et al., 1999a; Magnaghi et al., 2006). SC in culture, indeed, express the messengers for several GABA-A receptor subunits, that is $\alpha 2$ and 3, $\beta 1$, 2, and 3 (Melcangi et al., 1999a; Magnaghi et al., 2006).

Therefore, to investigate if the effect of ALLO on PMP22 expression was mediated by interaction with GABA-A receptors, ALLO's stimulation was mimicked with specific GABA-A ligands. Bicuculline, a specific GABA-A antagonist, abolishes the effect of ALLO on PMP22 expression levels, whereas muscimol (a specific GABAA agonist) mimics ALLO's action (Magnaghi et al., 2001, 2006), confirming the hypothesis that the expression of PMP22 in SC is under the control of GABA-A receptors. However, ALLO's action via the GABAergic system in SC is even more complex, because it also involves the GABA-B receptor and the endogenous GABA neurotransmitter (see Figure 1 for details).

Recent observations obtained by reverse transcriptasepolymerase chain reaction, western blot and immunohistochemistry analyses confirmed the presence of GABA-B receptor subunits $(1 \mathrm{a}, 1 \mathrm{~b}$, and 2$)$ in SC, where the functional receptor was proved to be negatively coupled to the adenylate cyclase system (Magnaghi et al., 2004). The activation of the GABA-B receptor in SC influences cell proliferation, as demonstrated with baclofen treatment that counteracted the forskolin-induced SC proliferation at 5 days in vitro (Magnaghi et al., 2004); at the same time point also the percentage of BrdUrd immunopositive SC was reduced (Magnaghi et al., 2004). Since the activation of the adenylate cyclase system potentially regulates SC proliferation (Lee et al., 1999; Mirsky and Jessen, 1999), we speculated that GABA-B-induced decrease in cAMP levels may affect the cell proliferation (Magnaghi et al., 2004). Notably, changes in cAMP levels in SC may also influence the expression of specific myelin proteins (Suter et al., 1994; Scherer et al., 1995; Lee et al., 1999). In agreement, GABA-B activation decreases the expression of some important myelin proteins, like P0, PMP22 as well as other proteins, like connexin 32 and the myelin associated glycoprotein (MAG; Magnaghi et al., 2004). 
Investigating the putative effects of neurosteroids on GABA$\mathrm{B}$ receptor subunits expression in the $\mathrm{SC}$ in vitro, it was also shown that ALLO controls the expression of different GABA-B receptor subunits (Magnaghi et al., 2006). The expression profile was biphasic; after $4 \mathrm{~h}$ of exposure ALLO produces a robust stimulation of the mRNA of all three subunits, $-1 a,-1 b$, and 2 , while at $24 \mathrm{~h}$ of exposure ALLO decreased the expression of $-1 \mathrm{~b}$ and -2 subunits (Magnaghi et al., 2006). Since ALLO's effect on GABA-B receptor expression was mimicked by muscimol and GABA, it was hypothesized that ALLO regulates GABA-B receptor via a GABA-A-mediated mechanism (Magnaghi et al., 2006; Magnaghi, 2007). The intracellular pathways downstream of this interaction is rather complicated and presently not completely identified, however a possible hypothesis is proposed below. After $24 \mathrm{~h}$ of exposure, $\mathrm{P}$ and DHP give rise to a GABA-B receptor modulation similar to that induced by ALLO. The longer time required leads to the hypothesis that $\mathrm{P}$ and DHP effects are due to their $5 \alpha-\mathrm{R}-3 \alpha$-HSD mediated conversion into ALLO (Magnaghi et al., 2006; Magnaghi, 2007). Therefore, GABA-B subunits expression may be differently influenced, mainly by ALLO via a GABA-Amediated mechanism, but also by its precursors $\mathrm{P}$ and/or DHP after $5 \alpha$-R-3 $\alpha$-HSD conversion into ALLO.
Most of the effects exerted by ALLO in SC were achieved at nanomolar concentration, involving an allosteric interaction that necessarily entails the presence of the endogenous ligand GABA. To make the issue even more puzzling, the presence of GABA and its synthetic machinery was thus demonstrated in SC. In particular the glutamic acid decarboxylase of $67 \mathrm{kDa}$ (GAD67), a key enzyme for GABA synthesis, was shown to be expressed in SC. Acting in a way that resemble an autocrine loop, ALLO $(10 \mathrm{nM})$ increased the levels of GAD67 in SC, thus stimulating GABA synthesis and providing the natural ligand for GABA-A receptor (Magnaghi et al., 2010).

Finally, in line with this hypothesis, it was recently demonstrated that SC in vitro possess a functionally active glutamate uptake system able to provide glutamate as a precursor for the synthesis of GABA (Perego et al., 2011). Indeed, it was first demonstrated that SC express the excitatory amino acid transporter 1 (EAAC1) in the plasma membrane and in intracellular vesicular compartments of the endocytic recycling pathway. Interestingly, EAAC1 activity can be modulated by exposure of SC to ALLO $10 \mathrm{nM}$. The transporter up-regulation by ALLO was rapid, did not involve protein neo-synthesis and was prevented by actin depolymerization. The modulation exerted by ALLO involved

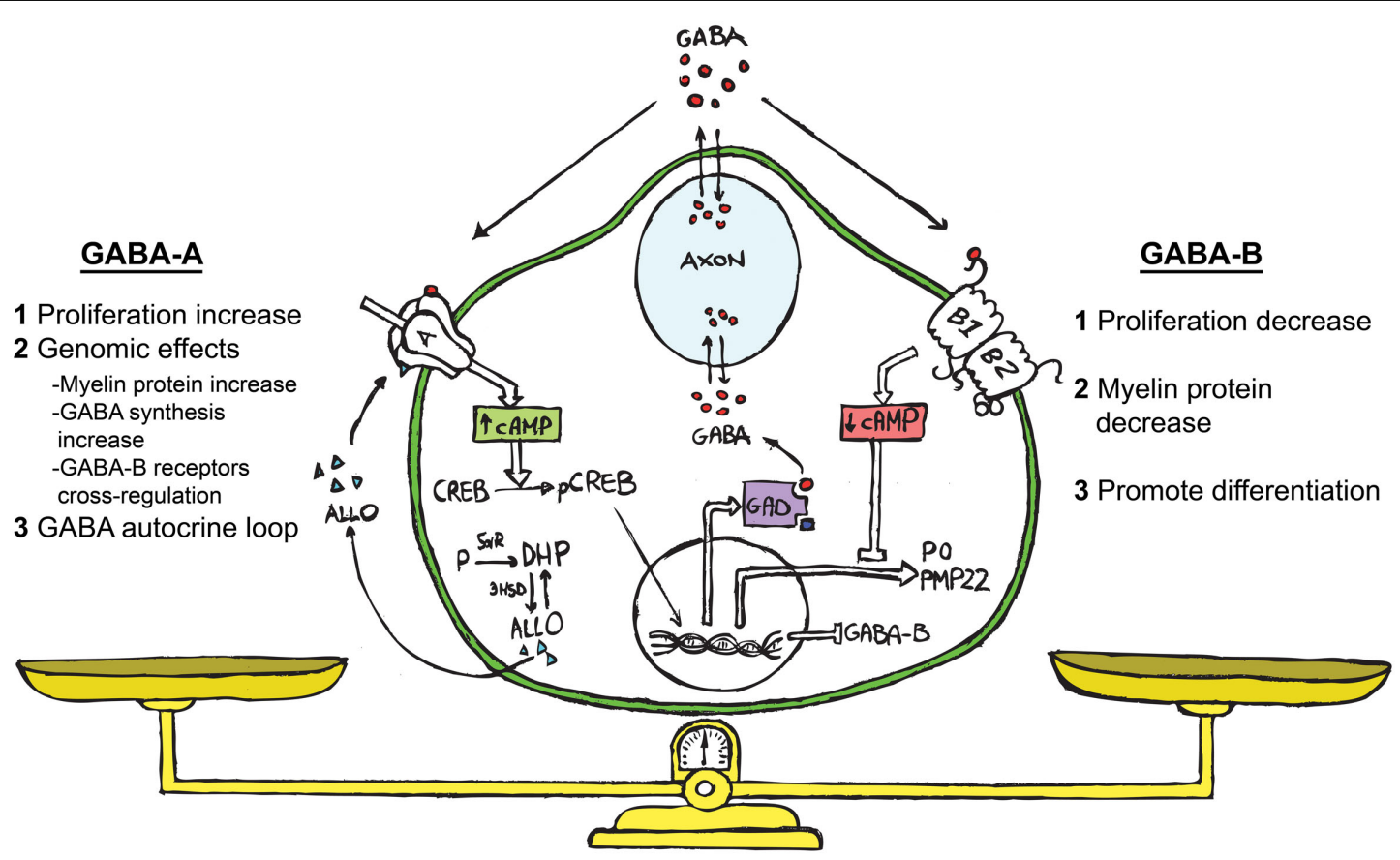

FIGURE 1 | Schematic representation showing ALLO, GABA and its receptors (GABA-A and GABA-B) acting in the bidirectional cross-talk between neurons and SC. We propose the following hypothesis on the functional role of the GABAergic system in SC. GABA, coming from the neuronal compartment or produced by the SC (Magnaghi et al., 2010), may affect the paracrine cross-talk between these cells. The extracellular GABA might interact with the GABA-B receptor on the SC surface, decreasing their proliferation (Magnaghi et al., 2004). This challenge then diminishes the cAMP levels, reducing the myelin proteins expression (Magnaghi et al., 2004) and prompts the SC to start differentiation. The neurosteroid ALLO, which is produced by SC (Baulieu and Schumacher, 1997; Melcangi et al., 1999b) allosterically activates the GABA-A receptor on the SC surface (Magnaghi et al., 2006). This modulates the expression and the responsiveness of the GABA-B receptor (Magnaghi et al., 2006, 2010), and in turn its desensitization. Contemporarily, ALLO stimulates the SC proliferation (Perego et al., 2011), inducing other genomic effects such as the increase of myelin proteins (Melcangi et al., 1999a; Magnaghi et al., 2001), and the rising of GAD and GABA levels (Magnaghi et al., 2010). The last effect, being a sort of autocrine mechanism, involving enhanced cAMP levels and the PK-A pathway. Collectively, these findings suggest that an autocrine mechanism involving ALLO and GABA is particularly relevant for the control of SC proliferation/differentiation, and may be considered the result of a balanced activation of GABA-A or GABA-B receptors on SC. 
GABA-A receptor and PK-C activation, promoting the exocytosis of the EAAC1 transporter from intracellular stores to the SC membrane (in actin-rich cell tips), and modifying the morphology of SC processes. The evidence that EAAC1 transporter controls the ALLO-mediated effects on SC proliferation was also provided (Perego et al., 2011).

\section{DOWNSTREAM MECHANISM FOLLOWING ALLO'S ACTIVATION OF GABA-A RECEPTOR: IS THE PUZZLE UNPUZZLED?}

Several attempts in the literature tried to explain the intracellular molecular mechanism downstream to ALLO's allosteric activation of GABA-A receptor, in neurons as well as in central and/or peripheral glial cells. For instance, in the developing rat cortex, GABA-A receptor activation leads to the opening of L-type voltage-gated calcium channels, resulting in an increase of calcium influx, which in turn leads to phosphorylation and activation of the transcription factor cAMP response element-binding protein (CREB) and finally controls neuronal nitric oxide synthase and brain derived neurotrophic factor expression (Mantelas et al., 2003). However, it should be underlined that the presence of endogenous GABA is the first precondition for ALLO's allosteric action. The synthesis of GABA was previously shown in astrocytes and oligodendrocytes, and very recently also in SC (Magnaghi et al., 2010).

Therefore, the interaction among the neurosteroid ALLO, GABA-A, and GABA-B receptors is relevant, at least in the PNS, for the bidirectional cross-talk between neurons and SC (Figure 1). GABA, coming from the neuronal compartment, or produced by SC (Magnaghi et al., 2010) may affect the paracrine interplay between these cells. In fact, data obtained with the specific GABA-B ligand baclofen suggest that extracellular GABA might interact with GABA-B receptors on SC, decreasing their proliferation, the cAMP levels and the myelin proteins expression. This effect promotes SC differentiation. ALLO produced by SC (Baulieu and Schumacher, 1997; Melcangi et al., 1999b) via a direct action on GABA-A receptor modulates the GABA-B receptor expression, distribution and responsiveness, and in turn its desensitization. Contemporarily, ALLO may increase some myelin

\section{REFERENCES}

Agis-Balboa, R. C., Pinna, G., Pibiri, F., Kadriu, B., Costa, E., and Guidotti, A. (2007). Down-regulation of neurosteroid biosynthesis in corticolimbic circuits mediates social isolationinduced behavior in mice. Proc. Natl. Acad. Sci. U.S.A. 104, 18736-18741.

Akk, G., Shu, H. J., Wang, C., Steinbach, J. H., Zorumski, C. F., Covey, D. F., and Mennerick, S. (2005). Neurosteroid access to the GABAA receptor. J. Neurosci. 25, 11605-11613.

Ardeshiri, A., Kelley, M. H., Korner, I. P., Hurn, P. D., and Herson, P. S. (2006). Mechanism of progesterone neuroprotection of rat cerebellar Purkinje cells following oxygen-glucose deprivation. Eur. J. Neurosci. 24, 2567-2574.

proteins expression in SC. Muscimol mimicked this effect on SC, further supporting that GABA-A might also participate in the control of the SC proliferation/differentiation (Figure 1).

However, the nature of the signaling pathways downstream to the ALLO's allosteric modulation of GABA-A receptor is still debated. We suggest an involvement of the protein kinase A (PKA) pathway, which through enhanced cAMP levels and CREB phosphorylation, modulates the allosteric action of ALLO at the GABA-A receptor (Magnaghi et al., 2010). However, other protein kinases should be also considered. In fact, the allosteric ALLO's modulation of GABA-A receptor, regulating glutamate uptake via EAAC1 transporter, is dependent by a PK-C activation, as confirmed by the very recent analysis of the pharmacological profile (Perego et al., 2011). Whether this relatively rapid ALLO's action on GABA-A receptor in glial cells may lead to ion channels opening, as occur in neuronal cells, should not be totally excluded and deserves further investigation.

\section{CONCLUSION}

In this review we focused our attention on the putative effects of ALLO on the glial cells of the CNS and PNS, with a particular emphasis on ALLO's regulation of glial physiology in normal and/or pathological conditions. The mechanism by which ALLO exerts these controls is part of the "non-genomic" action of steroids, involving the rapid modulation of neurotransmitter receptors such as the GABA receptors. However, ALLO's action on GABA-A receptor somehow involves downstream "genomic" mechanisms that are yet to be completely elucidated. In SC these intracellular mechanisms imply the activation of PK-A and PK-C signaling pathways, which in turn may determine the physiologic control of SC proliferation/differentiation. Nevertheless, an involvement of other intracellular pathways, for instance ion calcium channels, as observed in rat neuroprogenitor cells and human neural stem cells (Wang et al., 2005), should be further investigated.

\section{ACKNOWLEDGMENTS}

The authors are grateful to Dr. Ben Minogue, The University of Manchester, UK, for helpful discussion and reviewing of the manuscript.

Baulieu, E. E. (1997). Neurosteroids: a role in aging? New functions in the central and peripheral nervous systems. Aging (Milano) 9, 12.

Baulieu, E. E., and Schumacher, M. (1997). Neurosteroids, with special reference to the effect of progesterone on myelination in peripheral nerves. Mult. Scler. 3, 105-112.

Belachew, S., Malgrange, B., Rigo, J. M., Rogister, B., Coucke, P., Mazy-Servais, C., and Moonen, G. (1998). Developmental regulation of neuroligand-induced responses in cultured oligodendroglia. Neuroreport 9, 973-980.

Belelli, D., Casula, A., Ling, A., and Lambert, J. J. (2002). The influence of subunit composition on the interaction of neurosteroids with $\mathrm{GABA}(\mathrm{A})$ receptors. Neuropharmacology 43, 651-661.

Belelli, D., and Lambert, J. J. (2005). Neurosteroids: endogenous regulators of the GABA(A) receptor. Nat. Rev. Neurosci. 6, 565-575.

Ben-Ari, Y. (2002). Excitatory actions of gaba during development: the nature of the nurture. Nat. Rev. Neurosci. 3, 728-739.

Bender, A. S., and Norenberg, M. D. (1998). Effect of benzodiazepines and neurosteroids on ammoniainduced swelling in cultured astrocytes. J. Neurosci. Res. 54, 673-680.

Berger, T., Walz, W., Schnitzer, J., and Kettenmann, H. (1992). GABA- and glutamate-activated currents in glial cells of the mouse corpus callosum slice. J. Neurosci. Res. 31, 21-27. 
Borges, K., Wolswijk, G., Ohlemeyer, C., and Kettenmann, H. (1995). Adult rat optic nerve oligodendrocyte progenitor cells express a distinct repertoire of voltage- and ligand-gated ion channels. J. Neurosci. Res. 40, 591-605.

Bormann, J. (1988). Patch-clamp analysis of GABA- and glycine-gated chloride channels. Adv. Biochem. Psychopharmacol. 45, 47-60.

Bovolin, P., Santi, M. R., Puia, G., Costa, E., and Grayson, D. (1992). Expression patterns of gammaaminobutyric acid type A receptor subunit mRNAs in primary cultures of granule neurons and astrocytes from neonatal rat cerebella. Proc. Natl. Acad. Sci. U.S.A. 89, 9344-9348.

Bowery, N. G., and Enna, S. J. (2000). Gamma-aminobutyric acid(B) receptors: first of the functional metabotropic heterodimers. $J$. Pharmacol. Exp. Ther. 292, 2-7.

Bruce-Keller, A. J., Barger, S. W., Moss, N. I., Pham, J. T., Keller, J. N., and Nath, A. (2001). Proinflammatory and pro-oxidant properties of the HIV protein Tat in a microglial cell line: attenuation by 17 beta-estradiol. J. Neurochem. 78 , 1315-1324.

Brussaard, A. B., and Koksma, J. J. (2003). Conditional regulation of neurosteroid sensitivity of GABAA receptors. Ann. N. Y. Acad. Sci. 1007, 29-36.

Butt, A. M., and Jennings, J. (1994). Response of astrocytes to gammaaminobutyric acid in the neonatal rat optic nerve. Neurosci. Lett. 168, 53-56.

Callachan, H., Cottrell, G. A., Hather, N. Y., Lambert, J. J., Nooney, J. M., and Peters, J. A. (1987). Modulation of the GABAA receptor by progesterone metabolites. Proc. R. Soc. Lond. B Biol. Sci. 231, 359-369.

Cardona-Gomez, G. P., Doncarlos, L., and Garcia-Segura, L. M. (2000), Insulin-like growth factor I receptors and estrogen receptors colocalize in female rat brain. Neuroscience 99, 751-760.

Celotti, F., Melcangi, R. C., and Martini, L. (1992). The 5 alpha-reductase in the brain: molecular aspects and relation to brain function. Front. Neuroendocrinol. 13, 163-215.

Chisari, M., Eisenman, L. N., Krishnan, K., Bandyopadhyaya, A. K., Wang, C., Taylor, A., Benz, A., Covey, D. F., Zorumski, C. F., and Mennerick, S. (2009). The influence of neuroactive steroid lipophilicity on GABAA receptor modulation: evidence for a low-affinity interaction. J. Neurophysiol. 102, 1254-1264.
Chvatal, A., Pastor, A., Mauch, M., Sykova, E., and Kettenmann, H. (1995). Distinct populations of identified glial cells in the developing rat spinal cord slice: ion channel properties and cell morphology. Eur. J. Neurosci. 7, 129-142.

Conti, F., Barbaresi, P., Melone, M., and Ducati, A. (1999). Neuronal and glial localization of NR1 and NR2A/B subunits of the NMDA receptor in the human cerebral cortex. Cereb. Cortex 9, 110-120.

Conti, F., Debiasi, S., Minelli, A., and Melone, M. (1996). Expression of NR1 and NR2A/B subunits of the NMDA receptor in cortical astrocytes. Glia 17, 254-258.

Djebaili, M., Guo, Q., Pettus, E. H., Hoffman, S. W., and Stein, D. G. (2005). The neurosteroids progesterone and allopregnanolone reduce cell death, gliosis, and functional deficits after traumatic brain injury in rats. J. Neurotrauma 22, 106-118.

Dressing, G. E., Goldberg, J. E., Charles, N. J., Schwertfeger, K. L., and Lange, C. A. (2011). Membrane progesterone receptor expression in mammalian tissues: a review of regulation and physiological implications. Steroids 76, 11-17.

Drew, P. D., and Chavis, J. A. (2000). Female sex steroids: effects upon microglial cell activation. J. Neuroimmunol. 111, 77-85.

Evans, P. D., Reale, V., Merzon, R. M., and Villegas, J. (1991). N-methyl-Daspartate (NMDA) and non-NMDA type glutamate receptors are present on squid giant axon Schwann cells. J. Exp. Biol. 157, 593-600.

Evans, P. D., Reale, V., Merzon, R. M., and Villegas, J. (1992). Nmethyl-D-aspartate (NMDA) and non-NMDA (metabotropic) type glutamate receptors modulate the membrane potential of the Schwann cell of the squid giant nerve fibre. J. Exp. Biol. 173, 229-249.

Fink, T., Davey, D. F., and Ansselin, A. D. (1999). Glutaminergic and adrenergic receptors expressed on adult guinea pig Schwann cells in vitro. Can. J. Physiol. Pharmacol. 77, 204-210.

Finley, S. K., and Kritzer, M. F. (1999). Immunoreactivity for intracellular androgen receptors in identified subpopulations of neurons, astrocytes and oligodendrocytes in primate prefrontal cortex. J. Neurobiol. 40, 446-457.

Fraser, D. D., Duffy, S., Angelides, K. J., Perez-Velazquez, J. L., Kettenmann, H., and Macvicar, B. A. (1995). GABAA/benzodiazepine receptors in acutely isolated hippocampal astrocytes. J. Neurosci. 15 , 2720-2732.

Gago, N., Akwa, Y., Sananes, N., Guennoun, R., Baulieu, E. E., El-Etr, M. and Schumacher, M. (2001). Progesterone and the oligodendroglial lineage: stage-dependent biosynthesis and metabolism. Glia 36, 295-308.

Gago, N., El-Etr, M., Sananes, N., Cadepond, F., Samuel, D., AvellanaAdalid, V., Baron-Van Evercooren, A., and Schumacher, M. (2004). 3alpha,5alpha-Tetrahydroprogester one (allopregnanolone) and gam ma-aminobutyric acid: autocrine/ paracrine interactions in the control of neonatal PSA-NCAM+ progenitor proliferation. J. Neurosci. Res. 78, 770-783.

Garcia-Segura, L. M., Chowen, J. A., and Naftolin, F. (1996). Endocrine glia: roles of glial cells in the brain actions of steroid and thyroid hormones and in the regulation of hormone secretion. Front. Neuroendocrinol. 17, 180-211.

Garcia-Segura, L. M., Naftolin, F. Hutchison, J. B., Azcoitia, I., and Chowen, J. A. (1999). Role of astroglia in estrogen regulation of synaptic plasticity and brain repair. J. Neurobiol. 40, 574-584.

Ghezzi, P., Santo, E. D., Sacco, S., Foddi, C., Barbaccia, M. L., and Mennini, T. (2000). Neurosteroid levels are increased in vivo after LPS treatment and negatively regulate LPS-induced TNF production. Eur. Cytokine Netw. 11, 464-469.

Ghoumari, A. M., Ibanez, C., El-Etr, M., Leclerc, P., Eychenne, B., O’Malley, B. W., Baulieu, E. E., and Schumacher, M. (2003). Progesterone and its metabolites increase myelin basic protein expression in organotypic slice cultures of rat cerebellum. J. Neurochem. 86, 848-859.

Gilbert, P., Kettenmann, H., and Schachner, M. (1984a). Gammaaminobutyric acid directly depolarizes cultured oligodendrocytes. $J$. Neurosci. 4, 561-569.

Gilbert, P., Kettenmann, H., and Schachner, M. (1984b). Gammaaminobutyric acid directly depolarizes cultured oligodendrocytes. $J$. Neurosci. 4, 561-569.

Hammes, S. R., and Levin, E. R (2007). Extranuclear steroid receptors: nature and actions. Endocr. Rev. 28, 726-741.

Herbison, A. E. (2001). Physiological roles for the neurosteroid allopregnanolone in the modulation of brain function during pregnancy and parturition. Prog. Brain Res. 133 39-47.
Hirst, J. J., Yawno, T., Nguyen, P., and Walker, D. W. (2006). Stress in pregnancy activates neurosteroid production in the fetal brain. Neuroendocrinology 84, 264-274.

Hoppe, D., and Kettenmann, H. (1989). GABA triggers a Cl- efflux from cultured mouse oligodendrocytes. Neurosci. Lett. 97, 334-339.

Hosie, A. M., Clarke, L., Da Silva, H., and Smart, T. G. (2009). Conserved site for neurosteroid modulation of GABA A receptors. Neuropharmacology 56, 149-154.

Hosie, A. M., Wilkins, M. E., Da Silva, H. M., and Smart, T. G. (2006) Endogenous neurosteroids regulate GABAA receptors through two discrete transmembrane sites. Nature 444, 486-489.

Hosli, E., Otten, U., and Hosli, L. (1997). Expression of GABA(A) receptors by reactive astrocytes in explant and primary cultures of rat CNS. Int. J. Dev. Neurosci. 15, 949-960.

Ibanez, C., Shields, S. A., El-Etr, M., Leonelli, E., Magnaghi, V., Li, W. W., Sim, F. J., Baulieu, E. E., Melcangi, R. C., Schumacher, M., and Franklin, R. J. (2003). Steroids and the reversal of age-associated changes in myelination and remyelination. Prog. Neurobiol. 71, 49-56.

Israel, J. M., Schipke, C. G., Ohlemeyer, C., Theodosis, D. T., and Kettenmann, H. (2003). GABAA receptor-expressing astrocytes in the supraoptic nucleus lack glutamate uptake and receptor currents. Glia 44, 102-110.

Jessen, K. R., and Mirsky, R. (1997). Embryonic Schwann cell development: the biology of Schwann cell precursors and early Schwann cells. J. Anat. 191(Pt 4), 501-505.

Jordan, C. L. (1999). Glia as mediators of steroid hormone action on the nervous system: an overview. J. Neurobiol. 40, 434-445.

Jung-Testas, I., and Baulieu, E. E. (1998). Steroid hormone receptors and steroid action in rat glial cells of the central and peripheral nervous system. J. Steroid Biochem. Mol. Biol. 65, 243-251.

Jung-Testas, I., Renoir, M., Bugnard, H., Greene, G. L., and Baulieu, E. E. (1992). Demonstration of steroid hormone receptors and steroid action in primary cultures of rat glial cells. J. Steroid Biochem. Mol. Biol.41, 621-631.

Jung-Testas, I., Schumacher, M., Bugnard, H., and Baulieu, E. E. (1993). Stimulation of rat Schwann cell proliferation by estradiol: synergism between the estrogen and cAMP. Brain Res. Dev. Brain Res. 72, 282-290. 
Jung-Testas, I., Schumacher, M., Robel, P., and Baulieu, E. E. (1996a). Demonstration of progesterone receptors in rat Schwann cells. J. Steroid Biochem. Mol. Biol. 58, 77-82.

Jung-Testas, I., Schumacher, M., Robel, P., and Baulieu, E. E. (1996b). The neurosteroid progesterone increases the expression of myelin proteins (MBP and CNPase) in rat oligodendrocytes in primary culture. Cell. Mol. Neurobiol. 16, 439-443.

Kang, J., Jiang, L., Goldman, S. A., and Nedergaard, M. (1998). Astrocytemediated potentiation of inhibitory synaptic transmission. Nat. Neurosci. 1, 683-692.

Karadottir, R., Cavelier, P., Bergersen, L. H., and Attwell, D. (2005). NMDA receptors are expressed in oligodendrocytes and activated in ischaemia. Nature 438, 1162-1166.

Keller, E. A., Zamparini, A., Borodinsky, L. N., Gravielle, M. C., and Fiszman, M. L. (2004). Role of allopregnanolone on cerebellar granule cells neurogenesis. Brain Res. Dev. Brain Res. 153, 13-17.

Kelley, M. H., Kuroiwa, M., Taguchi, N., and Herson, P. S. (2011). Sex difference in sensitivity to allopregnanolone neuroprotection in mice correlates with effect on spontaneous inhibitory post synaptic currents. Neuropharmacology 61, 724-729.

Kettenmann, H., Backus, K. H., and Schachner, M. (1987). Gamma-aminobutyric acid opens Cl-channels in cultured astrocytes. Brain Res. 404, 1-9.

Kettenmann, H., Gilbert, P., and Schachner, M. (1984). Depolarization of cultured oligodendrocytes by glutamate and GABA. Neurosci. Lett. 47, 271-276.

Khanna, M., Qin, K. N., Wang, R. W., and Cheng, K. C. (1995). Substrate specificity, gene structure, and tissue-specific distribution of multiple human 3 alpha-hydroxysteroid dehydrogenases. J. Biol. Chem. 270, 20162-20168.

Kirchhoff, F., and Kettenmann, $\mathrm{H}$. (1992). GABA triggers a $[\mathrm{Ca} 2+] \mathrm{i}$ increase in murine precursor cells of the oligodendrocyte lineage. Eur. J. Neurosci. 4, 1049-1058.

Koenig, H. L., Schumacher, M., Ferzaz, B., Thi, A. N., Ressouches, A., Guennoun, R., Jung-Testas, I., Robel, P., Akwa, Y., and Baulieu, E. E. (1995). Progesterone synthesis and myelin formation by Schwann cells. Science 268, 1500-1503.

Krebs, C., Fernandes, H. B., Sheldon, C., Raymond, L. A., and Baimbridge, K. G. (2003). Functional NMDA receptor subtype $2 \mathrm{~B}$ is expressed in astrocytes after ischemia in vivo and anoxia in vitro. J. Neurosci. 23, 3364-3372.

Kuo, J., Hamid, N., Bondar, G., Prossnitz, E. R., and Micevych, P. (2011). Membrane estrogen receptors stimulate intracellular calcium release and progesterone synthesis in hypothalamic astrocytes. J. Neurosci. 30, 12950-12957.

Labombarda, F., Meffre, D., Delespierre, B., Krivokapic-Blondiaux, S., Chastre, A., Thomas, P., Pang, Y., Lydon, J. P., Gonzalez, S. L., De Nicola, A. F., Schumacher, M., and Guennoun, R. (2011). Membrane progesterone receptors localization in the mouse spinal cord. Neuroscience 166, 94-106.

Lalo, U., Pankratov, Y., Kirchhoff, F., North, R. A., and Verkhratsky, A. (2006). NMDA receptors mediate neuron-to-glia signaling in mouse cortical astrocytes. J. Neurosci. 26, 2673-2683

Lambert, J. J., Belelli, D., Hill-Venning, C., Callachan, H., and Peters, J. A. (1996). Neurosteroid modulation of native and recombinant GABAA receptors. Cell. Mol. Neurobiol. 16, 155-174.

Lambert, J. J., Belelli, D., Hill-Venning, C., and Peters, J. A. (1995). Neurosteroids and GABAA receptor function. Trends Pharmacol. Sci. 16, 295-303.

Lambert, J. J., Belelli, D., Peden, D. R., Vardy, A. W., and Peters, J. A. (2003). Neurosteroid modulation of GABAA receptors. Prog. Neurobiol. 71, 67-80.

Lambert, J. J., Cooper, M. A., Simmons, R. D., Weir, C. J., and Belelli, D. (2009). Neurosteroids: endogenous allosteric modulators of GABA(A) receptors. Psychoneuroendocrinology 34(Suppl. 1), S48-S58.

Langub, M. C. Jr., and Watson, R. E. Jr. (1992). Estrogen receptorimmunoreactive glia, endothelia, and ependyma in guinea pig preoptic area and median eminence: electron microscopy. Endocrinology 130, 364-372.

Laping, N. J., Teter, B., Nichols, N. R., Rozovsky, I., and Finch, C. E. (1994). Glial fibrillary acidic protein: regulation by hormones, cytokines, and growth factors. Brain Pathol. 4, 259-275.

Lee, M., Mcgeer, E. G., and Mcgeer, P. L. (2011a). Mechanisms of GABA release from human astrocytes. Glia 59, 1600-1611.

Lee, M., Schwab, C., and Mcgeer, P. L. (2011b). Astrocytes are GABAergic cells that modulate microglial activity. Glia 59, 152-165.
Lee, M. M., Badache, A., and Devries, G. H. (1999). Phosphorylation of CREB in axon-induced Schwann cell proliferation. J. Neurosci. Res. 55, 702-712.

Levin, E. R. (2011). Minireview: extranuclear steroid receptors: roles in modulation of cell functions. Mol. Endocrinol. 25, 377-384.

Macvicar, B. A., Tse, F. W., Crichton, S. A., and Kettenmann, H. (1989). GABA-activated Cl- channels in astrocytes of hippocampal slices. J. Neurosci. 9, 3577-3583.

Magnaghi, V. (2007). GABA and neuroactive steroid interactions in glia: new roles for old players? Curr. Neuropharmacol. 5, 47-64.

Magnaghi, V., Ballabio, M., Cavarretta, I. T., Froestl, W., Lambert, J. J., Zucchi, I., and Melcangi, R. C. (2004). GABAB receptors in Schwann cells influence proliferation and myelin protein expression. Eur. J. Neurosci. 19, 2641-2649.

Magnaghi, V., Ballabio, M., Consoli, A., Lambert, J. J., Roglio, I., and Melcangi, R. C. (2006). GABA receptormediated effects in the peripheral nervous system: a cross-interaction with neuroactive steroids. $\mathrm{J} . \mathrm{Mol}$. Neurosci. 28, 89-102.

Magnaghi, V., Cavarretta, I., Galbiati, M., Martini, L., and Melcangi, R. C. (2001). Neuroactive steroids and peripheral myelin proteins. Brain Res. Brain Res. Rev. 37, 360-371.

Magnaghi, V., Cavarretta, I., Zucchi, I. Susani, L., Rupprecht, R., Hermann, B., Martini, L., and Melcangi, R. C. (1999). Po gene expression is modulated by androgens in the sciatic nerve of adult male rats. Brain Res. Mol. Brain Res. 70, 36-44.

Magnaghi, V., Parducz, A., Frasca, A. Ballabio, M., Procacci, P., Racagni, G., Bonanno, G., and Fumagalli, F. (2010). GABA synthesis in Schwann cells is induced by the neuroactive steroid allopregnanolone. J. Neurochem. 112, 980-990.

Maguire, J., and Mody, I. (2009). Steroid hormone fluctuations and GABA(A)R plasticity. Psychoneuroendocrinology 34(Suppl. 1), S84S90.

Majewska, M. D. (1992). Neurosteroids: endogenous bimodal modulators of the GABAA receptor. Mechanism of action and physiological significance. Prog. Neurobiol. 38, 379-395.

Majewska, M. D., Harrison, N. L., Schwartz, R. D., Barker, J. L., and Paul, S. M. (1986). Steroid hormone metabolites are barbituratelike modulators of the GABA receptor. Science 232, 1004-1007.

Mantelas, A., Stamatakis, A., Kazanis, I., Philippidis, H., and Stylianopoulou,
F. (2003). Control of neuronal nitric oxide synthase and brain-derived neurotrophic factor levels by GABAA receptors in the developing rat cortex. Brain Res. Dev. Brain Res. 145, 185-195.

Martini, L., Magnaghi, V., and Melcangi, R. C. (2003). Actions of progesterone and its 5alpha-reduced metabolites on the major proteins of the myelin of the peripheral nervous system. Steroids 68, 825-829.

Matsutani, S., and Yamamoto, N. (1997). Neuronal regulation of astrocyte morphology in vitro is mediated by GABAergic signaling. Glia 20, 1-9.

Melcangi, R. C., Cavarretta, I., Magnaghi, V., Martini, L., and Galbiati, M. (2001a). Interactions between growth factors and steroids in the control of LHRH-secreting neurons. Brain Res. Brain Res. Rev. 37, 223-234.

Melcangi, R. C., Magnaghi, V., Galbiati, M., and Martini, L. (2001b). Formation and effects of neuroactive steroids in the central and peripheral nervous system. Int. Rev. Neurobiol. 46, 145-176.

Melcangi, R. C., Magnaghi, V., Galbiati, M., and Martini, L. (2001c). Formation and effects of neuroactive steroids in the central and peripheral nervous system. Int. Rev. Neurobiol. 46, 145-176.

Melcangi, R. C., Celotti, F., Ballabio, M., Castano, P., Massarelli, R., Poletti, A., and Martini, L. (1990a). 5 alpha-reductase activity in isolated and cultured neuronal and glial cells of the rat. Brain Res. 516, 229-236.

Melcangi, R. C., Celotti, F., Ballabio, M., Poletti, A., and Martini, L. (1990b) Testosterone metabolism in peripheral nerves: presence of the 5 alphareductase-3 alpha-hydroxysteroiddehydrogenase enzymatic system in the sciatic nerve of adult and aged rats. J. Steroid Biochem. 35, 145-148.

Melcangi, R. C., Celotti, F., Ballabio, M., Castano, P., Poletti, A., Milani, S., and Martini, L. (1988). Ontogenetic development of the 5 alphareductase in the rat brain: cerebral cortex, hypothalamus, purified myelin and isolated oligodendrocytes. Brain Res. Dev. Brain Res. 44, 181-188.

Melcangi, R. C., Celotti, F., Castano, P., and Martini, L. (1992) Is the 5 alpha-reductase- 3 alphahydroxysteroid dehydrogenase complex associated with the myelin in the peripheral nervous system of young and old male rats? Endocr. Regul. 26, 119-125. 
Melcangi, R. C., Celotti, F., Castano, P., and Martini, L. (1993). Differential localization of the 5 alpha-reductase and the 3 alpha-hydroxysteroid dehydrogenase in neuronal and glial cultures. Endocrinology 132, 1252-1259.

Melcangi, R. C., Celotti, F., and Martini, L. (1994). Progesterone 5-alphareduction in neuronal and in different types of glial cell cultures: type 1 and 2 astrocytes and oligodendrocytes. Brain Res. 639, 202-206.

Melcangi, R. C., Galbiati, M., Messi, E., Magnaghi, V., Cavarretta, I., Riva, M. A., and Zanisi, M. (1997). Astrocyteneuron interactions in vitro: role of growth factors and steroids on LHRH dynamics. Brain Res. Bull. 44, 465-469.

Melcangi, R. C., Magnaghi, V., Cavarretta, I., Martini, L., and Piva, F. (1998). Age-induced decrease of glycoprotein Po and myelin basic protein gene expression in the rat sciatic nerve. Repair by steroid derivatives. Neuroscience 85, 569-578.

Melcangi, R. C., Magnaghi, V., Cavarretta, I., Zucchi, I., Bovolin, P., D’Urso, D., and Martini, L. (1999a). Progesterone derivatives are able to influence peripheral myelin protein 22 and P0 gene expression: possible mechanisms of action. J. Neurosci. Res. 56, 349-357.

Melcangi, R. C., Magnaghi, V., and Martini, L. (1999b). Steroid metabolism and effects in central and peripheral glial cells. J. Neurobiol. 40, 471-483.

Melcangi, R. C., Magnaghi, V., Galbiati, M., Ghelarducci, B., Sebastiani, L., and Martini, L. (2000a). The action of steroid hormones on peripheral myelin proteins: a possible new tool for the rebuilding of myelin? J. Neurocytol. 29, 327-339.

Melcangi, R. C., Magnaghi, V., and Martini, L. (2000b). Aging in peripheral nerves: regulation of myelin protein genes by steroid hormones. Prog. Neurobiol. 60, 291-308.

Melcangi, R. C., Magnaghi, V., and Martini, L. (2000c). Aging in peripheral nerves: regulation of myelin protein genes by steroid hormones. Prog. Neurobiol. 60, 291-308.

Melcangi, R. C., Riva, M. A., Fumagalli, F., Magnaghi, V., Racagni, G., and Martini, L. (1996). Effect of progesterone, testosterone and their 5 alpha-reduced metabolites on GFAP gene expression in type 1 astrocytes. Brain Res. 711, 10-15.

Mellon, S. H., Griffin, L. D., and Compagnone, N. A. (2001). Biosynthesis and action of neurosteroids. Brain Res. Brain Res. Rev. 37, 3-12.

Micu, I., Jiang, Q., Coderre, E., Ridsdale, A., Zhang, L., Woulfe, J., Yin, X., Trapp, B. D., Mcrory, J. E., Rehak, R.,
Zamponi, G. W., Wang, W., and Stys, P. K. (2006). NMDA receptors mediate calcium accumulation in myelin during chemical ischaemia. Nature 439, 988-992.

Mihalek, R. M., Banerjee, P. K., Korpi, E. R., Quinlan, J. J., Firestone, L. L., Mi, Z. P., Lagenaur, C., Tretter, V., Sieghart, W., Anagnostaras, S. G., Sage, J. R., Fanselow, M. S., Guidotti, A., Spigelman, I., Li, Z., Delorey, T. M., Olsen, R. W., and Homanics, G. E. (1999). Attenuated sensitivity to neuroactive steroids in gamma-aminobutyrate type A receptor delta subunit knockout mice. Proc. Natl. Acad. Sci. U.S.A. 96, 12905-12910.

Milner, T. A., Mcewen, B. S., Hayashi, S., Li, C. J., Reagan, L. P., and Alves, S. E. (2001). Ultrastructural evidence that hippocampal alpha estrogen receptors are located at extranuclear sites. J. Comp. Neurol. 429, 355-371.

Mirsky, R., and Jessen, K. R. (1999). The neurobiology of Schwann cells. Brain Pathol. 9, 293-311.

Monnet, F. P., and Maurice, T. (2006). The sigmal protein as a target for the non-genomic effects of neuro(active)steroids: molecular, physiological, and behavioral aspects. J. Pharmacol. Sci. 100, 93-118.

Nguyen, L., Malgrange, B., Breuskin, I., Bettendorff, L., Moonen, G., Belachew, S., and Rigo, J. M. (2003). Autocrine/paracrine activation of the $\mathrm{GABA}(\mathrm{A})$ receptor inhibits the proliferation of neurogenic polysialylated neural cell adhesion molecule-positive (PSA$\mathrm{NCAM}+$ ) precursor cells from postnatal striatum. J. Neurosci. 23, 3278-3294.

Nichols, N. R. (1999). Glial responses to steroids as markers of brain aging. $J$. Neurobiol. 40, 585-601.

Ojeda, S. R., and Ma, Y. J. (1999). Glial-neuronal interactions in the neuroendocrine control of mammalian puberty: facilitatory effects of gonadal steroids. J. Neurobiol. 40, 528-540.

Park-Chung, M., Malayev, A., Purdy, R. H., Gibbs, T. T., and Farb, D. H. (1999). Sulfated and unsulfated steroids modulate gammaaminobutyric acid A receptor function through distinct sites. Brain Res. 830, 72-87.

Pastor, A., Chvatal, A., Sykova, E., and Kettenmann, H. (1995). Glycineand GABA-activated currents in identified glial cells of the developing rat spinal cord slice. Eur. J. Neurosci. 7, 1188-1198.

Perego, C., Cairano, E. S., Ballabio, M., and Magnaghi, V. (2011).
Neurosteroid allopregnanolone regulates EAAC1-mediated glutamate uptake and triggers actin changes in Schwann cells. J. Cell. Physiol. doi: 10.1002/jcp. 22898

Puia, G., Santi, M. R., Vicini, S., Pritchett, D. B., Purdy, R. H., Paul, S. M., Seeburg, P. H., and Costa, E. (1990). Neurosteroids act on recombinant human GABAA receptors. Neuron 4 759-765.

Roglio, I., Bianchi, R., Gotti, S., Scurati, S., Giatti, S., Pesaresi, M., Caruso, D., Panzica, G. C., and Melcangi, R. C. (2008). Neuroprotective effects of dihydroprogesterone and progesterone in an experimental model of nerve crush injury. Neuroscience 155, 673-685.

Rosewater, K., and Sontheimer, H. (1994). Fibrous and protoplasmic astrocytes express GABAA receptors that differ in benzodiazepine pharmacology. Brain Res. 636, 73-80.

Rupprecht, R., Di Michele, F., Hermann, B., Strohle, A., Lancel, M., Romeo, E., and Holsboer, F. (2001). Neuroactive steroids: molecular mechanisms of action and implications for neuropsychopharmacology. Brain Res. Brain Res. Rev. 37, 59-67.

Rupprecht, R., and Holsboer, F. (1999). Neuroactive steroids: mechanisms of action and neuropsychopharmacological perspectives. Trends Neurosci. 22, 410-416.

Salter, M. G., and Fern, R. (2005). NMDA receptors are expressed in developing oligodendrocyte processes and mediate injury. Nature 438, 1167-1171.

Santagati, S., Melcangi, R. C., Celotti, F., Martini, L., and Maggi, A. (1994). Estrogen receptor is expressed in different types of glial cells in culture. J. Neurochem. 63, 2058-2064.

Scherer, S. S., Deschenes, S. M., Xu, Y. T., Grinspan, J. B., Fischbeck, K. H., and Paul, D. L. (1995). Connexin32 is a myelin-related protein in the PNS and CNS. J. Neurosci. 15, 8281-8294.

Schipke, C. G., Ohlemeyer, C., Matyash, M., Nolte, C., Kettenmann, H., and Kirchhoff, F. (2001). Astrocytes of the mouse neocortex express functional N-methyl-D-aspartate receptors. FASEB J. 15, 1270-1272.

Sedlacek, M., Korinek, M., Petrovic, M., Cais, O., Adamusova, E., Chodounska, H., and Vyklicky, L. Jr. (2008). Neurosteroid modulation of ionotropic glutamate receptors and excitatory synaptic transmission. Physiol Res 57(Suppl. 3), S49-S57.

Sereda, M. W., Meyer Zu Horste, G., Suter, U., Uzma, N., and Nave, K. A. (2003). Therapeutic administration of progesterone antagonist in a model of Charcot-Marie-Tooth disease (CMT-1A). Nat. Med. 9, 1533-1537.

Shu, H. J., Eisenman, L. N., Jinadasa, D., Covey, D. F., Zorumski, C. F., and Mennerick, S. (2004). Slow actions of neuroactive steroids at GABAA receptors. J. Neurosci. 24, 6667-6675.

Sim, J. A., Skynner, M. J., and Herbison, A. E. (2001). Direct regulation of postnatal GnRH neurons by the progesterone derivative allopregnanolone in the mouse. Endocrinology 142, 4448-4453.

Singh, S., Hota, D., Prakash, A., Khanduja, K. L., Arora, S. K., and Chakrabarti, A. (2010). Allopregnanolone, the active metabolite of progesterone protects against neuronal damage in picrotoxin-induced seizure model in mice. Pharmacol. Biochem. Behav. 94, 416-422.

Slater, E. P., Hesse, H., and Beato, M. (1994). Regulation of transcription by steroid hormones. Ann. N. Y. Acad. Sci. 733, 103-112.

Steckelbroeck, S., Watzka, M., Reichelt, R., Hans, V. H., Stoffel-Wagner, B., Heidrich, D. D., Schramm, J., Bidlingmaier, F., and Klingmuller, D. (2001). Characterization of the 5alpha-reductase-3alphahydroxysteroid dehydrogenase complex in the human brain. J. Clin. Endocrinol. Metab. 86, 1324-1331.

Stone, D. J., Rozovsky, I., Morgan, T. E., Anderson, C. P., Hajian, H., and Finch, C. E. (1997). Astrocytes and microglia respond to estrogen with increased apoE mRNA in vivo and in vitro. Exp. Neurol. 143, 313-318.

Suter, U., Snipes, G. J., Schoener-Scott, R., Welcher, A. A., Pareek, S., Lupski, J. R., Murphy, R. A., Shooter, E. M., and Patel, P. I. (1994). Regulation of tissue-specific expression of alternative peripheral myelin protein22 (PMP22) gene transcripts by two promoters. J. Biol. Chem. 269, 25795-25808.

Thi, A. D., Jung-Testas, I., and Baulieu, E. E. (1998). Neuronal signals are required for estrogen-mediated induction of progesterone receptor in cultured rat Schwann cells. J. Steroid Biochem. Mol. Biol. 67, 201-211.

Vegeto, E., Bonincontro, C., Pollio, G., Sala, A., Viappiani, S., Nardi, F., Brusadelli, A., Viviani, B., Ciana, P., and Maggi, A. (2001). Estrogen prevents the lipopolysaccharideinduced inflammatory response in microglia. J. Neurosci. 21, 1809-1818.

Vegeto, E., Pollio, G., Pellicciari, C., and Maggi, A. (1999). Estrogen and progesterone induction of survival of monoblastoid cells undergoing TNF-alpha-induced apoptosis. FASEB J. 13, 793-803. 
Verdi, J. M., and Campagnoni, A. T. (1990). Translational regulation by steroids. Identification of a steroid modulatory element in the 5'untranslated region of the myelin basic protein messenger RNA. J. Biol. Chem. 265, 20314-20320.

Vergnano, A. M., Schlichter, R., and Poisbeau, P. (2007). PKC activation sets an upper limit to the functional plasticity of GABAergic transmission induced by endogenous neurosteroids. Eur. J. Neurosci. 26, 1173-1182.

Von Blankenfeld, G., Trotter, J., and Kettenmann, H. (1991). Expression and developmental regulation of a GABAA receptor in cultured murine cells of the oligodendrocyte lineage. Eur. J. Neurosci. 3, 310-316.

Wang, C., Pralong, W. F., Schulz, M. F., Rougon, G., Aubry, J. M., Pagliusi, S., Robert, A., and Kiss, J. Z. (1996). Functional N-methyl$\mathrm{D}$-aspartate receptors in $\mathrm{O}-2 \mathrm{~A}$ glial precursor cells: a critical role in regulating polysialic acid-neural cell adhesion molecule expression and cell migration. J. Cell Biol. 135, 1565-1581.

Wang, J. M., Johnston, P. B., Ball, B. G., and Brinton, R. D. (2005). The neurosteroid allopregnanolone promotes proliferation of rodent and human neural progenitor cells and regulates cell-cycle gene and protein expression. J. Neurosci. 25, 4706-4718.

Whiting, P. J., Mcallister, G., Vassilatis, D., Bonnert, T. P., Heavens, R. P., Smith, D. W., Hewson, L. O’Donnell, R., Rigby, M. R., Sirinathsinghji, D. J., Marshall, G., Thompson, S. A., Wafford, K. A., and Vasilatis, D. (1997). Neuronally restricted RNA splicing regulates the expression of a novel GABAA receptor subunit conferring atypical functional properties. J. Neurosci. 17, 5027-5037.

Whiting, P. J., Mckernan, R. M., and Wafford, K. A. (1995). Structure and pharmacology of vertebrate GABAA receptor subtypes. Int. Rev. Neurobiol. 38, 95-138.

Williamson, A. V., Mellor, J. R., Grant, A. L., and Randall, A. D. (1998). Properties of GABA(A) receptors in cultured rat oligodendrocyte progenitor cells. Neuropharmacology 37, 859-873.

Yokoi, H., Tsuruo, Y., Miyamoto, T., and Ishimura, K. (1998). Steroid 5 alpha-reductase type 1 immunolocalized in the adrenal gland of normal, gonadectomized, and sex hormone-supplemented rats. Histochem. Cell Biol. 109, 127-134.

Ziak, D., Chvatal, A., and Sykova, E. (1998). Glutamate-, kainate- and NMDA-evoked membrane currents in identified glial cells in rat spinal cord slice. Physiol. Res. 47, 365-375.

Conflict of Interest Statement: The authors declare that the research was conducted in the absence of any commercial or financial relationships that could be construed as a potential conflict of interest.

Received: 30 July 2011; paper pending published: 23 September 2011; accepted: 05 December 2011; published online: 28 December 2011.

Citation: Faroni $A$ and Magnaghi $V$ (2011) The neurosteroid allopregnanolone modulates specific functions in central and peripheral glial cells. Front. Endocrin. 2:103. doi: 10.3389/fendo.2011.00103

This article was submitted to Frontiers in Neuroendocrine Science, a specialty of Frontiers in Endocrinology.

Copyright (C) 2011 Faroni and Magnaghi. This is an open-access article distributed under the terms of the Creative Commons Attribution Non Commercial License, which permits non-commercial use, distribution, and reproduction in other forums, provided the original authors and source are credited. 